\title{
Influence of wood-derived biochar on the physico-mechanical and chemical characteristics of agricultural soils
}

\author{
Ahmed S.F. Ahmed* and Vijaya Raghavan \\ Department of Bioresource Engineering, McGill University, Sainte-Anne-de-Bellevue, Quebec, Canada \\ Received November 13, 2016; accepted December 29, 2017
}

\begin{abstract}
Amendment of soil with biochar has been shown to enhance fertility and increase crop productivity, but the specific influence of biochar on soil workability remains unclear. Select physico-mechanical and chemical properties of clay loam and sandy loam soils were measured after amendment with wood-derived biochar of two particle size ranges (0.5-425 and 425$850 \mu \mathrm{m})$ at five dosages ranging from 0.5 to $10 \%$ dry weight. Whereas the clay loam soil workability decreased when the finer wood-derived biochar was applied at rates of 6 or $10 \%$, soil fertility was not enhanced. The sandy loam soil, due to Proctor compaction, significantly decreased in bulk density with 6 and $10 \%$ wood-derived biochar amendments indicating higher soil resistance to compaction.
\end{abstract}

Keyw ords: biochar, particle size, Proctor compaction, plasticity, soil workability

\section{INTRODUCTION}

Biochar is produced by pyrolysis, a process whereby biomass is decomposed in the absence of oxygen at temperatures of $250-700^{\circ} \mathrm{C}$ (Yuan et al., 2014). Pyrolysis conditions and feedstock material influence the chemical composition and physical structure of biochar (Cimò et al., 2014). Wood-derived biochar (WBC) with particle diameters $<2 \mu \mathrm{m}$ had skeletal and particle densities of 1.96 and $0.60 \mathrm{~g} \mathrm{~cm}^{-3}$, respectively (Brewer et al., 2014; Mitchell et al., 2015), and a surface area of $75 \mathrm{~m}^{2} \mathrm{~g}^{-1}$.

Application of WBC to soils could alter soil workability $(W)$, as assessed through the soil plastic limit $\left(\theta_{p l}\right)$, optimum moisture content $\left(\theta_{\text {opt }}\right)$ for tillage, and aggregate tensile strength $\left(\sigma_{t}\right)$. Soil $W$ is directly linked to friability - the tendency of a mass of soil to crumble into smaller aggregates

*Corresponding author e-mail: ahmed.ahmed@mcgill.ca of certain size range under an applied stress (Utomo and Dexter, 1981). Soil aggregate $\sigma_{t}$ and friability are indications of soil structural quality (Reis et al., 2014). Friability could determine the damage done to the soil structure by tillage (Watts and Dexter, 1998). Soil $W$ is inversely linked to aggregate $\sigma_{t}$ (Arthur et al., 2014) the force per unit area required to disrupt the aggregate. Thus, $W$ combines friability and the energy needed to fragment the soil clods. The clay and silt contents of soils greatly increase the $\sigma_{t}$ of soils (Imhoff et al., 2002).

In addition, soil fertility has been shown to improve after WBC amendment; the degree of improvement depends on the amount of WBC applied and the incubation period of the mixture (Li et al., 2016).

Application of $6 \%$ dry weight. WBC decreased the soil liquid limit $\left(\theta_{l l}\right.$; the $\theta$ at which the soil changes from a plastic state to a liquid state), increased the $\theta_{p l}$ (the $\theta$ at which the soil changes from a semi-solid state to a plastic state) and consequently decreased the plasticity index $\left(P I=\theta_{p l}-\theta_{l l}\right)$ of a clayey soil (Zong et al., 2016). However, the effect on $\theta_{p l}$, could become less significant as soil clay content increases, as noted by $\mathrm{Qu}$ et al. (2014) for rice-husk ash amendment. The amended clayey soil also showed lower cohesion (c) and higher internal friction $(\varphi)$. Soil $\mathrm{c}$ is the result of the bonding between soil particles, whereas $\varphi$ is the resistance to movement of soil particles when a shear force is applied (Zong et al., 2016). Such changes have implications in farm management, since WBC amendment can reduce soil shear strength $(\tau)$ (Blanco-Moure et al., 2012; Zong et al., 2016). 
The objective of this research project was to determine the effects of amendment with different particle sizes of WBC on the $W$ and fertility (organic matter (OM) content, nutrient composition, $\mathrm{pH}$, cation exchange capacity (CEC), and ash content) of two soil types differing in texture, pore size distribution, and clay and sand content: a clay loam (CL) and a sandy loam (SL) soils.

\section{MATERIALS AND METHODS}

The CL and SL soils were collected from the A horizon $(0-0.20 \mathrm{~m})$ of two fields $\left(45^{\circ} 25^{\prime} 35.5^{\prime \prime} \mathrm{N}, 73^{\circ} 55^{\prime} 37.0^{\prime \prime} \mathrm{W}\right.$ and $45^{\circ} 25^{\prime} 35.8^{\prime \prime} \mathrm{N}, 73^{\circ} 56^{\prime} 21.1^{\prime \prime} \mathrm{W}$ ) in the MacDonald Campus Farm, McGill University (Sainte-Anne-deBellevue, QC). The soil samples were air-dried at room temperature and ground to pass through a $2 \mathrm{~mm}$ sieve. The WBC, purchased from a local market (Charbon de Bois Feuille d'Érable Inc., Sainte-Christine d'Auvergne, QC), was produced by the thermal (at $500^{\circ} \mathrm{C}$ ) decomposition of forest wastes, including maple (Acer sp.) wood. The WBC was ground to the desired particle sizes in a blender.

Soil particle size was analyzed according to the ASTM D7928 (ASTM International 2017). The smallest particle size of WBC $(0.5 \mu \mathrm{m})$ was determined by a laser diffraction method, using a SympaTEC-HELOS/BF laser diffraction sensor (Clausthal-Zellerfeld, Germany) (Rees et al., 2014). The ground WBC was sieved in a fumehood into two particles size ranges: $0.5-425 \mu \mathrm{m}\left(\mathrm{PS}_{1}\right)$, and $425-850 \mu \mathrm{m}\left(\mathrm{PS}_{2}\right)$, Thus, for each soil type, the design included 2 particle size ranges $\times 5 \mathrm{WBC}$ dosages (Table 1 ).

To achieve the desired WBC content, dry soil and WBC were homogenized for $20 \mathrm{~min}$ in a soil mixer. Triplicate soil samples containing WBC of $0.5,1.75,3,6$, and $10 \%$ dry weight were used in the experiments (Table 1), which corresponds to field applications of 18.8, 65.6, 112.5, 225, and $375 \mathrm{tha}^{-1}$, respectively, assuming a soil $\rho$ in the field of $1.25 \mathrm{t} \mathrm{m}^{-3}$ and an application depth of $30 \mathrm{~cm}$.

The uncompacted soil (loose and dry) bulk density $\left(\rho_{\mathrm{O}}\right)$ was determined by dividing the oven-dry mass of the soil, $\mathrm{WBC}$, or WBC-amended soil by its volume. The soil maximum bulk density $\left(\rho_{\max }\right)$ and $\theta_{o p t}$ were determined through a standard Proctor compaction test in line with ASTM D698-07 (ASTM International 2007), using a compaction effort of 25 rammer blows.
Soil consistency limits in terms of $\theta_{p l}$ and $\theta_{l l}$ were determined as the Atterberg limits by following ASTM D4318-10 (ASTM International, 2010).

The soil shear parameters $(\varphi$ and $c$ ) were accertained by the standard shear box method (Lu et al., 2014) and ASTM D3080 / D3080M-11 (ASTM International, 2005).

Soil aggregates were obtained from air-dried soil carefully fragmented by hand during the drying process, following the procedures outlined by Elmholt et al. (2008). Soil aggregate samples with a diameter of 30 or $50 \mathrm{~mm}$ were crushed (Dexter and Kroesbergen, 1985; Dexter and Bird, 2000) using a universal testing machine (INSTRON Model 5565) with a constant speed of $4 \mathrm{~mm} \mathrm{~s}^{-1}$.

Equation (1) was used to calculate the $\sigma_{t}(\mathrm{kPa})$ of each soil aggregate (Utomo and Dexter, 1981):

$$
\sigma_{t}=\frac{0.576 F}{d^{2}}
$$

where: $F$ is the polar force $(\mathrm{N})$ needed to fracture the aggregate, and $d$ is the mean aggregate diameter (m).

Soil friability index $(F I)$ values were calculated from the $\sigma_{t}$ measurements of different aggregate sizes (Getahun et al., 2016). The dimensionless $F I$ is estimated from the variation of $\sigma_{t}$ of various aggregate sizes about their mean, as shown in Eq. (2) (Watts and Dexter, 1998).

$$
F I=\frac{\sigma_{\sigma_{t}}}{\sigma_{t}},
$$

where: $\sigma_{\sigma t}$ is the standard deviation of the tensile strength of various aggregates sizes, and $\sigma_{t}$ is the mean tensile strength.

If $F I<0.1$, the soil aggregate is not friable; if $F I=0.1$ 0.2 , it is slightly friable; $F I=0.2-0.5$, it is friable; if $F I=$ $0.5-0.8$, it is very friable; and if $F I \geq 0.8$, the aggregate is mechanically unstable (Imhoff et al., 2002).

Soil $W$ is calculated as the ratio of friability to mean $\sigma_{t}$, as shown in Eq. (3) (Arthur et al., 2014):

$$
W=\frac{F I}{\sigma_{t}} .
$$

Low $W$ values indicate unsuitability of soil for fragmentation at a given energy input (Getahun et al., 2016).

The OM, nutrient composition, $\mathrm{pH}, \mathrm{CEC}$, and ash content of soil, WBC, and soil-WBC mixtures were determined by dry combustion (Slepetiene et al., 2008), the Mehlich-3 extraction method (Mehlich, 1984), a pH me-

Table 1. Loose bulk density $\left(\rho_{\mathrm{o}}\right)$, maximum density $\left(\rho_{\max }\right)$, optimum moisture content $\left(\theta_{\text {opt }}\right)$, and relative increase in bulk density $\left(\left(\rho_{\max }\right.\right.$ $\left.\left.-\rho_{\mathrm{o}}\right) / \rho_{\mathrm{o}}\right)$ of non-amended soils

Physical properties

\begin{tabular}{cccccc} 
Type & Characteristics & $\rho_{\mathrm{o}}\left(\mathrm{Mg} \mathrm{m}^{-3}\right)$ & $\rho_{\max }\left(\mathrm{Mg} \mathrm{m}^{-3}\right)$ & $\theta_{\mathrm{opt}}(\%)$ & $\frac{\rho_{\max }-\rho_{\mathrm{o}}}{\rho_{\mathrm{o}}}$ \\
\hline \multirow{2}{*}{ Soil } & Clay loam & 0.987 & 1.532 & 17 & 0.55 \\
& Sandy loam & 1.195 & 1.674 & 11.9 & 0.40 \\
\hline
\end{tabular}


ter (Carter, 1993), the $\mathrm{BaCl}_{2}$ method (Hendershot et al., 1993), and ASTM D1762-84 (ASTM International, 2013), respectively.

Analysis of variance (ANOVA) and the Duncan's Multiple Range Test were used for testing mean differences in the responses using the SAS software program (v. 9.2, SAS Institute, Cary, NC).

\section{RESULTS AND DISCUSSION}

The CL and SL soils were well-graded. Hydrometer analysis showed that the CL soil contained $37 \%$ clay, $27 \%$ silt, and $26 \%$ sand. By comparison, the SL soil contained $5 \%$ clay, $20 \%$ silt, and $75 \%$ sand.

Unamended CL and SL soils had RID $\left(\left(\rho_{\max }-\rho_{\mathrm{O}}\right) / \rho_{\mathrm{O}}\right)$ values of 0.55 and 0.40 , respectively (Table 2 ). The $\theta_{\text {opt }}$ for the $\rho_{\max }$ was higher in the CL soil - with higher clay content - than the SL soil, as reported by Larson et al. (1980), Craig (1974), and Barzegar et al. (2000). Therefore, the CL soil is more susceptible to compaction than the SL soil.

After amendment with $\mathrm{PS}_{1}$ WBC, both the $\rho_{\mathrm{O}}$ and $\rho_{\max }$ decreased: at 6 and $10 \%$ dosages, the mean $\rho_{\mathrm{O}}$ decreased by $12.7(p=0.05)$ and $16.1 \%(p=0.05)$ in CL soil, respectively, and by $4.1(\mathrm{p}=0.05)$ and $3.9 \%(\mathrm{p}=0.05)$ in SL soil, respectively (Table 3, Fig. 1). At 6 and $10 \% \mathrm{WBC}$, the mean $\rho_{\max }$ decreased by $7.3(\mathrm{p}=0.05)$ and $10.6 \%(\mathrm{p}=0.05)$ in CL soil, respectively, and by $10.1(\mathrm{p}=0.05)$ and $13.9 \%(\mathrm{p}=$ 0.05 ) in SL soil. Dosages of 0.5 and $1.75 \% \mathrm{PS}_{1} \mathrm{WBC}$ (and in general the $3 \%$ dosage) did not affect the $\rho_{\mathrm{O}}, \rho_{\max }$ or $\theta_{\text {opt }}$ of the two soil types ( $p>0.05)$. Thus, the highest dosages of the fine WBC particles caused a more dramatic decline in $\rho_{\mathrm{O}}$ in CL soils than SL soils, but a similar magnitude decline in $\rho_{\max }$. This meant that, whereas the RID increased in the CL soil by approximately $18 \%$ at 6 and $10 \% \mathrm{PS}_{1} \mathrm{WBC}(\mathrm{p}$ $=0.05$ ), it actually decreased in the SL soil by 22 and $36 \%$, respectively (Table 3 ). In CL soil, the $\theta_{\text {opt }}$ increased by 22 $(\mathrm{p}=0.05)$ and $32 \%(\mathrm{p}=0.05)$ at 6 and $10 \% \mathrm{WBC} \mathrm{PS}_{1}$, respectively, and by about double these values in SL soils.

With the exception of a $6.3 \%$ decrease in mean $\rho_{\max }$ $(p=0.05)$, the CL soil was not affected by amendment with the coarser $\mathrm{WBC}\left(\mathrm{PS}_{2}\right)$ (Table 3). However, the SL soil was affected by a similar magnitude by $\mathrm{PS}_{2}$ treatment as it was to $\mathrm{PS}_{1}$ : the SL soil $\rho_{\mathrm{O}}$ and $\rho_{\max }$ decreased at the two higher WBC dosages, the RID also decreased $(p=0.05)$, and the the $\theta_{\text {opt }}$ increased $(\mathrm{p}=0.05)$. This difference in response related to soil texture could be attributed to the fact that the larger SL soil pores could accommodate more particles of $\mathrm{PS}_{2} \mathrm{WBC}$, resulting in a significant decrease in $\rho_{\max }$ and increase in $\theta_{o p t}$ for both particle size amendments (Fig. 2).

Ta ble 2. Loose bulk density $\left(\rho_{\mathrm{o}}\right)$, maximum density $\left(\rho_{\max }\right)$, optimum moisture content $\left(\theta_{\text {opt }}\right)$, relative increase in bulk density (RID) of soils after amendment with WBC-PS or $\mathrm{WBC} \mathrm{PS}_{2}$ at different rates

\begin{tabular}{|c|c|c|c|c|c|c|c|c|}
\hline \multirow{5}{*}{$\begin{array}{c}\text { Biochar } \\
\text { amendment } \\
\text { (\% dry weight) }\end{array}$} & \multicolumn{8}{|c|}{ Biochar particle diameter } \\
\hline & \multicolumn{4}{|c|}{ WBS-PS $_{1}$} & \multicolumn{4}{|c|}{$\mathrm{WBC}-\mathrm{PS}_{2}$} \\
\hline & \multicolumn{4}{|c|}{$0.5-425 \mu \mathrm{m}$} & \multicolumn{4}{|c|}{$425-850 \mu \mathrm{m}$} \\
\hline & $\rho_{\mathrm{o}}$ & $\rho_{\max }$ & $\theta_{\text {opt }}$ & \multirow{2}{*}{ RID } & $\rho_{\mathrm{o}}$ & $\rho_{\max }$ & $\theta_{\mathrm{opt}}$ & \multirow{2}{*}{ RID } \\
\hline & \multicolumn{2}{|c|}{$\left(\mathrm{Mg} \mathrm{m}^{-3}\right)$} & $(\%)$ & & \multicolumn{2}{|c|}{$\left(\mathrm{Mg} \mathrm{m}^{-3}\right)$} & \multirow[t]{2}{*}{$(\%)$} & \\
\hline & & & & & & & & \\
\hline 0.5 & 0.942 & 1.5 & 17.1 & 0.59 & 0.977 & 1.54 & 16 & 0.58 \\
\hline 1.75 & 0.912 & 1.48 & 18.5 & 0.57 & 0.969 & 1.512 & 15.8 & 0.56 \\
\hline 3 & 0.896 & 1.46 & 19.5 & 0.63 & 0.925 & 1.490 & 17 & 0.61 \\
\hline 6 & 0.862 & 1.42 & 20.7 & 0.65 & 0.931 & 1.485 & 17.5 & 0.53 \\
\hline \multirow[t]{2}{*}{10} & 0.828 & 1.37 & 22.5 & 0.65 & 0.928 & 1.436 & 17.4 & 0.55 \\
\hline & \multicolumn{8}{|c|}{ Sandy loam } \\
\hline 0.5 & 1.185 & 1.65 & 12 & 0.39 & 1.194 & 1.67 & 15.5 & 0.4 \\
\hline 1.75 & 1.188 & 1.606 & 12.8 & 0.35 & 1.187 & 1.64 & 16.2 & 0.38 \\
\hline 3 & 1.116 & 1.555 & 15.0 & 0.35 & 1.145 & 1.63 & 16.8 & 0.42 \\
\hline 6 & 1.146 & 1.505 & 17.5 & 0.31 & 1.125 & 1.465 & 17.0 & 0.3 \\
\hline 10 & 1.148 & 1.442 & 19.5 & 0.28 & 1.125 & 1.455 & 17.8 & 0.29 \\
\hline
\end{tabular}

Values in bold differ significantly $(\mathrm{p} \leq 0.05)$ from equivalent. 
Table 3. Influence of WBC particle size and application rate on CL soil plasticity parameters

\begin{tabular}{|c|c|c|c|c|c|c|c|c|}
\hline \multirow{5}{*}{$\begin{array}{c}\text { Biochar } \\
\text { amendment } \\
\text { (\% dry weight })\end{array}$} & \multicolumn{8}{|c|}{ Biochar particle diameter } \\
\hline & \multicolumn{4}{|c|}{$\mathrm{PS}_{1}$} & \multicolumn{4}{|c|}{$\mathrm{PS}_{2}$} \\
\hline & \multicolumn{4}{|c|}{$0.5-425 \mu \mathrm{m}$} & \multicolumn{4}{|c|}{$425-850 \mu \mathrm{m}$} \\
\hline & $\theta_{p l} *$ & $\theta_{l l}^{*}$ & $P I^{*}$ & $\Delta P I^{* *}$ & $\theta_{p l}$ & $\theta_{l l}$ & $P I$ & $\Delta P I$ \\
\hline & \multicolumn{8}{|c|}{$(\%)$} \\
\hline 0.5 & 19.8 & 49.3 & 29.5 & 3.2 & 20 & 51.0 & 31.0 & 4.7 \\
\hline 1.75 & 20.8 & 50.0 & 29.25 & 2.9 & 20.0 & 44.4 & 24.4 & 1.9 \\
\hline 3 & 22.0 & 55.7 & 33.7 & 7.4 & 21.0 & 53.0 & 32.0 & 5.7 \\
\hline 6 & 23.0 & 57.6 & 34.6 & 8.3 & 20.7 & 55.5 & 34.8 & 8.5 \\
\hline 10 & 26.2 & 59.7 & 33.5 & 7.2 & 22.0 & 54.8 & 32.8 & 6.5 \\
\hline
\end{tabular}

*Relative $\%$ difference, **absolute difference, values in bold differ significantly $(\mathrm{p} \leq 0.05)$ from non amended CL soil, whose $\theta_{p l}, \theta_{l l}$, and $P I$ are $21.9,48.2$ and $26.3 \%$, respectively.

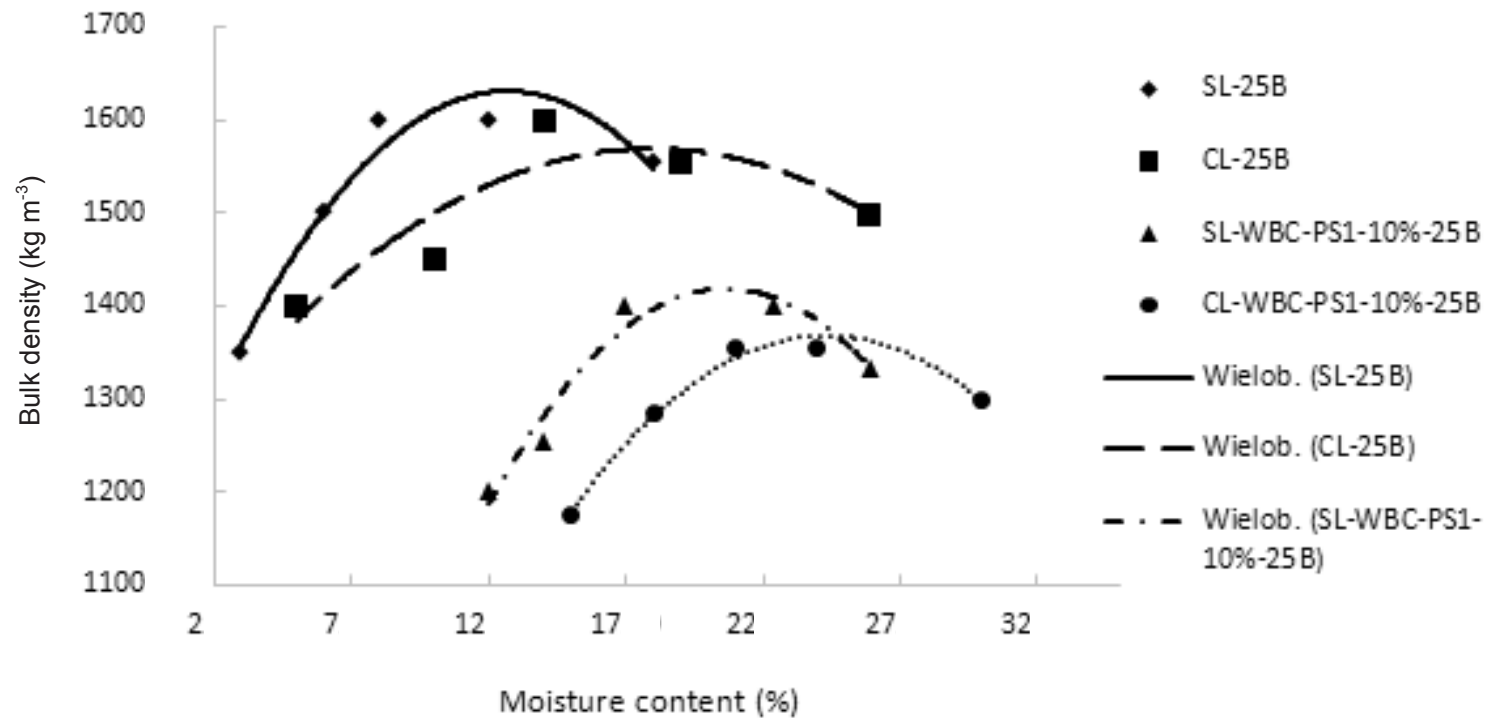

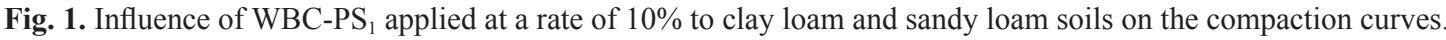

These results suggest that the addition of $\mathrm{WBC} \mathrm{PS}_{1}$ to CL soil could extend the range of the CL soil $W$, without causing compaction (Fig. 3). The relatively small particles of WBC could make the CL soil more prone to compaction.

The $10 \% \mathrm{PS}_{1}$ amendment decreased the $\rho_{\mathrm{O}}$ of the CL by $16 \%$ and decreased the $\rho_{\max }$ by $7.3 \%$. but had an opposite trend in the SL, because it decreased the $\rho_{\mathrm{O}}$ to $3.9 \%$ and decreased the $\rho_{\max }$ to $10 \%$. This means that the RID of the SL decreased by $22 \%$ (from 10 to $3.9 \%$ ) and increased by $10 \%$ (from 7.3 to $16 \%$ ) in the CL. This could only be attributed to the fact that the $\theta_{o p t}$ of the SL increased by $70 \%$ whereas the CL increased only by $30 \%$ due to the $10 \% \mathrm{PS}_{1}$ amendment.
The $\theta_{p l}, \theta_{l l}$, and $P I$ of the unamended CL soil were 21.9, 48.2 , and $26.3 \%$, respectively, whereas the SL soil showed no plasticity. Table 3 illustrates the variations in the consistency limits of the CL soil as amended with WBC-PS and $\mathrm{WBC}^{-} \mathrm{PS}_{2}$ at various rates. Amendment of the $\mathrm{CL}$

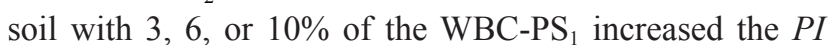
by $0.1,1.1$ and $4.3 \%$, respectively, relative to unamended soil. The $\theta_{l l}$ values for the same WBC-PS $S_{1}$ amendments significantly $(\mathrm{p} \leq 0.05)$ increased with an increase in the application doses. For the same amendment rates, both WBC-PS ${ }_{1}$ and WBC-PS ${ }_{2}$ amendments led to a significant $(\mathrm{p} \leq 0.05)$ increase in the PI. The difference in the values of the $P I$ between the WBC-PS $\mathrm{S}_{1}$ and $\mathrm{WBC}^{-\mathrm{PS}_{2}}$ amended $\mathrm{CL}$ soil were not significant $(\mathrm{p} \leq 0.05)$. Furthermore, the effect 


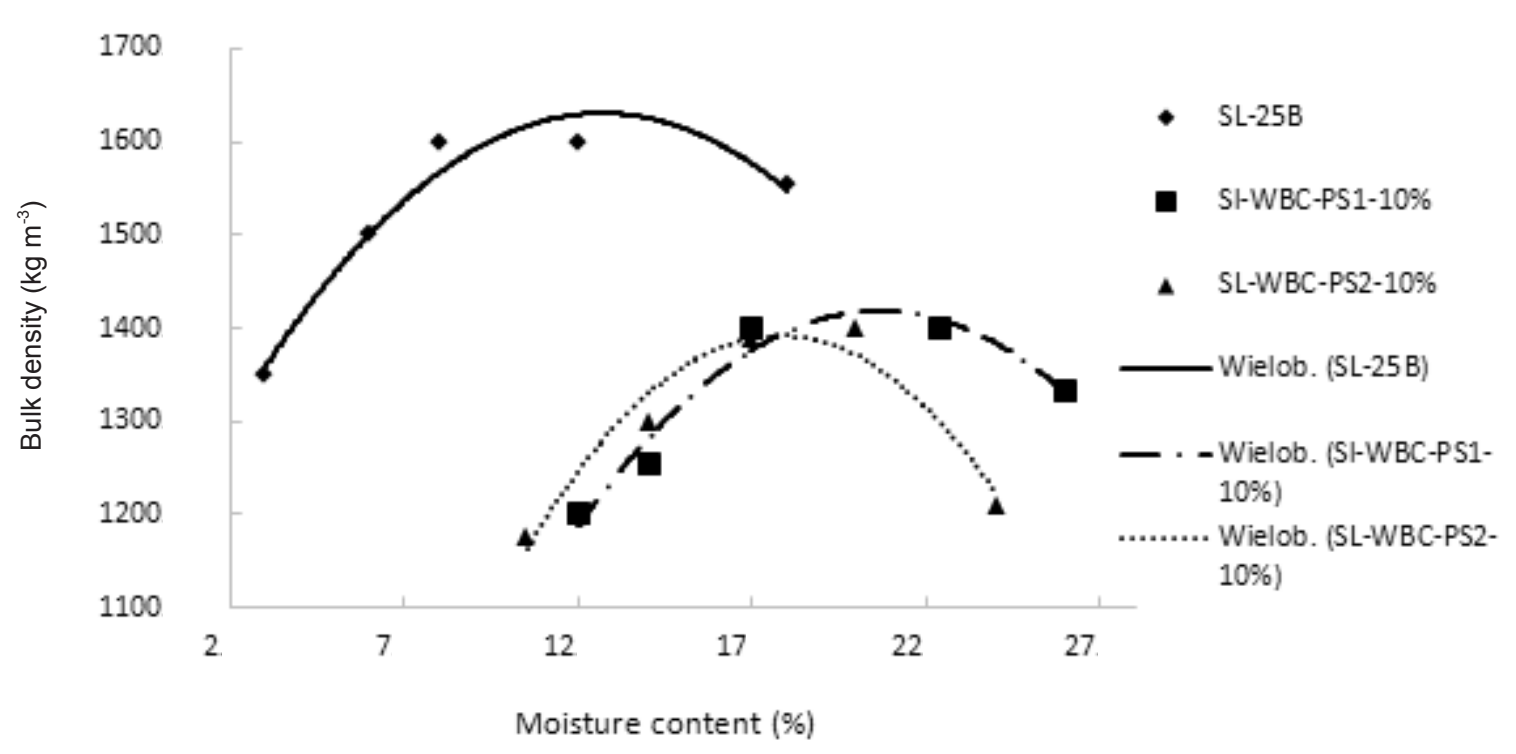

Fig. 2. Influence of WBC particle sizes applied at a rate of $10 \%$ to the SL soil on the compaction curves.

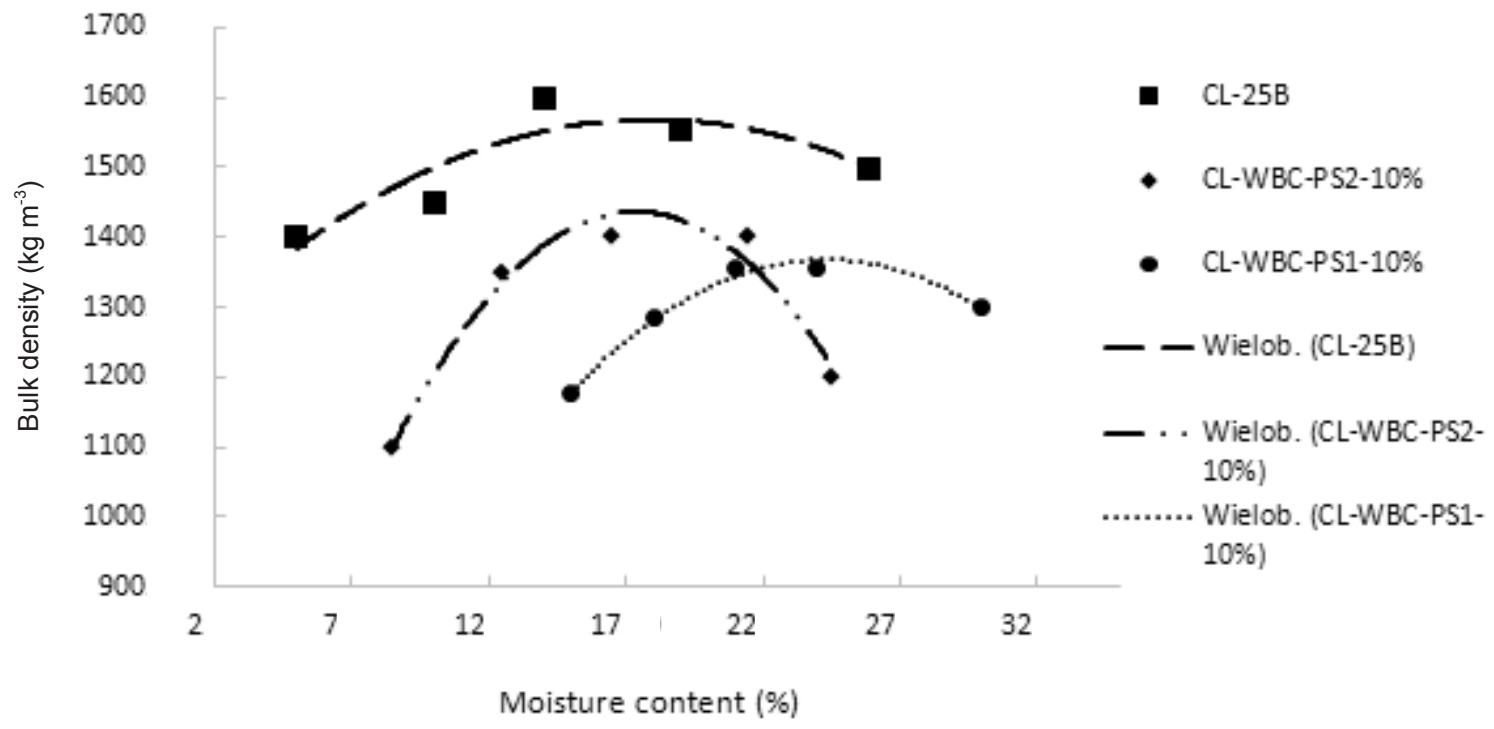

Fig. 3. Influence of WBC particle sizes applied at a rate of $10 \%$ to the CL soil on the compaction curves.

of increasing the WBC-PS 2 application dose on the CL soil $P I$ was not consistent. Given the important role of the value of the $\theta_{l l}$ on the $P I$, the similarity of the $P I$ response can be attributed to the relatively small increase in $\theta_{p l}$ of the WBC-PS ${ }_{2}$ amended soils compared to that of the WBC-PS ${ }_{1}$. The increase in $\theta_{p l}$ for the WBC-PS 1 was significant at $6 \%$ and $10 \%$ amendment rates only, whereas, the increase in $\theta_{l l}$ for the WBC-PS ${ }_{1}$ amendment was greater than that for WBC-PS ${ }_{2}$ amendments. This inconsistency minimized the significant differences in the $P I$ values of the soils amended with WBC-PS 1 and WBC-PS 2 . According to Mapfumo and Chanasyk (1998a) a $P I<7$ indicates a soil of low plasticity, whereas $7<P I<17$ indicates medium plasticity, and $P I>17$ indicates high plasticity. Since clayey soils exhibit high plasticity and are therefore highly prone to compaction, the CL soil amended with WBC has higher PI-given the larger moisture range within which deformation could occur - does not render soil more prone to compaction than unamended soil.

It can be inferred from Tables 3 and 4 that the $\theta_{p l}$ of the CL soils increased due to the increase in $\theta_{\text {opt }}$ with increasing WBC $\mathrm{PS}_{1}$ dosage. By simple linear regression, the relationship $\left(\mathrm{R}^{2}=0.94 ; \mathrm{p}=0.05\right)$ between $\theta_{p l}$ and $\theta_{\text {opt }}$ for $\mathrm{CL}$ soil amended with 3,6 , and $10 \% \mathrm{WBC}^{\mathrm{PS}} \mathrm{P}_{1}$ is found as:

$$
\theta_{\text {opt }}=0.68 \theta_{p l}+4.8
$$


The simple regression analysis with the $\mathrm{WBC}-\mathrm{PS}_{2}$ did not show a strong correlation between the $\theta_{p l}$ and the $\theta_{\text {opt }}(r=0.41)$.

Untreated SL soil had 64\% lower $c$ than CL soil (Fig. 4). The 6 and $10 \% \mathrm{PS}_{1}$ WBC amended CL soils had lower $c$ values ( $\mathrm{p}=0.05$ and 0.05 , respectively) than unamended CL soils, whereas the 3, 6, and $10 \% \mathrm{PS}_{1} \mathrm{WBC}$ amended SL soils had lower $c$ values $(\mathrm{p}=0.05,0.05$, and 0.05 , respectively) than unamended SL soils.

Compared to an unamended SL, an increase ( $\mathrm{p} \leq 0.05)$ in $\varphi$ was found upon amendment of the soil with WBC$\mathrm{PS}_{1}$ at dosages of $1.75,3,6$, and $10 \%$ dry weight and with $\mathrm{WBC}-\mathrm{PS}_{2}$ at a rate of $10 \%$. There was an increase $(\mathrm{p}<0.05)$ in the $\varphi$ of the CL soil when it was amended with WBC-PS at rates of $1.75,3,6$, and $10 \%$ dry weight (Fig. 5).

Given the influence on soil failure of the thrust force under tractor tires and in front of a tillage tool, a decrease in the soil $c$ and an increase in soil $\varphi$ would require alternating agricultural machinery and practices. For example, since an increase in $\varphi$ would be beneficial under high tractor loads, amendment with finer WBC would be recommended when heavy tractors are used (large-scale farms). Conversely, a decrease in the soil $c$ would require wider tractor tires to overcome the reduced $c$ of soil. Therefore, relatively coarse WBC amendment would be recommended in small-scale farms or wider wheels when smaller WBC particle sizes are applied. Conversely, in front of a tillage tool, the force required to cut the soil will be reduced when finer WBC is applied to CL soil at dosages of 6 or $10 \%$. This is because a decrease in the value of $c$ and $\varphi$ would have a minimal effect on the cutting action.

Untreated CL soil aggregates exhibited nearly 10 -fold higher $(\mathrm{p}=0.05) \sigma_{t}$ than SL soil aggregates (Fig. 6). The presence of $\mathrm{PS}_{1} \mathrm{WBC}$ at dosages of $0.5-10 \%$ reduced the mean $\sigma_{t}$ of CL soil aggregates by $10-47 \%(\mathrm{p}=0.05)$, with the maximum change observed for the $10 \%$ treatment. For the coarser $\mathrm{WBC}$, only the 3, 6, and $10 \%$ treatments decreased the mean $\sigma_{t}$ in the CL soil. By comparison, the $\sigma_{t}$ of SL soil aggregates was less sensitive to WBC amendment, only showing a decrease $(\mathrm{p}=0.05$ and 0.05$)$ at 6 and $10 \%$ amendment with WBC PS 1 and no change $(\mathrm{p}>0.05)$ with WBC PS ${ }_{2}$.

The FI of untreated CL soil was nearly 8 -fold higher than the FI of untreated SL soil (Table 5). $10 \%$ WBC $\mathrm{PS}_{1}$ amendment decreased the $F I$ of CL soil by $48 \%$ (p $=$ $0.05)$, but did not change $(\mathrm{p}=0.05)$ the $F I$ of SL soil. By comparison, whereas $10 \% \mathrm{WBC} \mathrm{PS}_{2}$ amendment, did not change the FI of CL soil, the FI of SL increased by $133 \%$ $(\mathrm{p}=0.05)$. Friability and aggregate $\sigma_{t}$ are an indication of soil $W$. Therefore, the CL soil $W$ decreased from 691 to

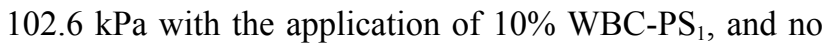
significant changes in the $W$ of the CL soil was observed with the addition of $\mathrm{WBC}^{-\mathrm{PS}_{2}}$ at the same application rate.

There was no significant differences in the $\mathrm{pH}$ of the WBCs of different particle sizes, but the WBC with smaller particle size had a significantly higher $\mathrm{P}, \mathrm{K}, \mathrm{Ca}$ and $\mathrm{Mg}$ levels than the WBC with larger particle size $(\mathrm{p} \leq 0.01)$. This difference in nutrients release is attributed to the relatively high surface area of the smaller particle size of WBC compared to the larger particle size of the WBC. The unamended SL soil had a higher $\mathrm{pH}, \mathrm{P}$ and $\mathrm{Al}$ but lower $\mathrm{K}$ and $\mathrm{Mg}$ nutrient levels than the CL soil (Table 6).

When the CL and the SL soils were amended with WBC

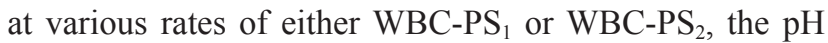
values were changed significantly $(\mathrm{p} \leq 0.05)$ (shown in bold in Table 5). In contrast, the $\mathrm{P}, \mathrm{K}, \mathrm{Ca}, \mathrm{Mg}$ and $\mathrm{Al}$ values were not changed significantly when WBC-PS $\mathrm{S}_{1}$ or $\mathrm{WBC}^{\mathrm{P}} \mathrm{PS}_{2}$ were amended to the $\mathrm{CL}$ soil (Table 6). In another study, $\mathrm{CL}$

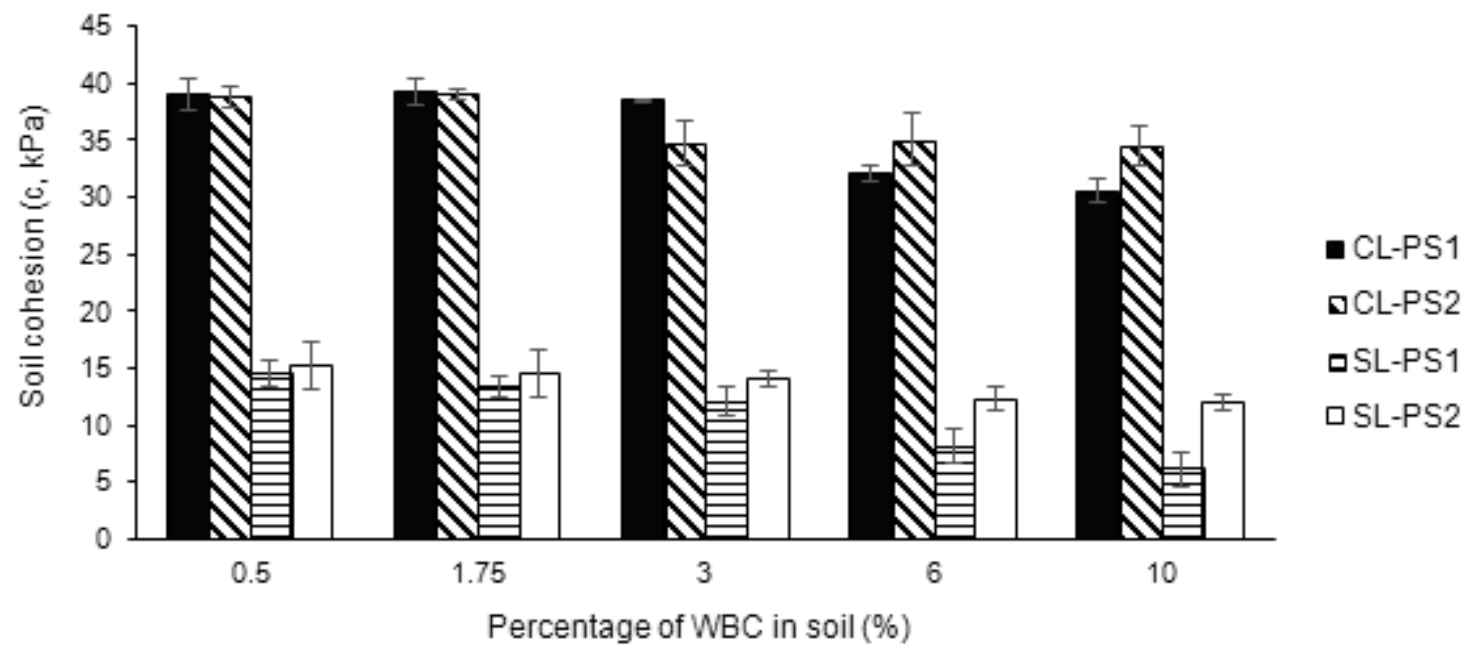

Fig. 4. Influence of the amendment of the SL and CL soils with different rates (\% dry weight) of small $\left(\mathrm{PS}_{1}\right)$ or large $\left(\mathrm{PS}_{2}\right)$ particle size WBC on soil cohesion. 


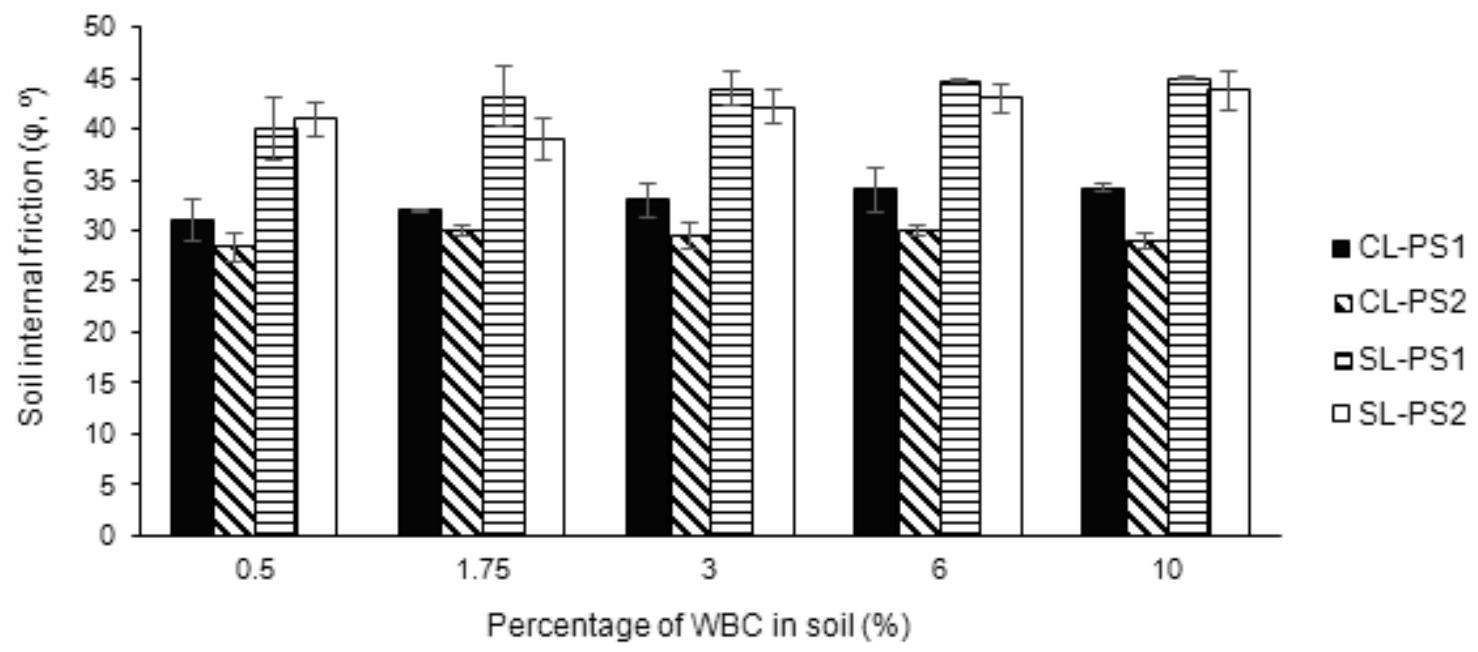

Fig. 5. Influence of the amendment of the CL soil with different rates (\% dry weight) of small $\left(\mathrm{PS}_{1}\right)$ or large $\left(\mathrm{PS}_{2}\right)$ particle size $\mathrm{WBC}$ on soil internal friction.

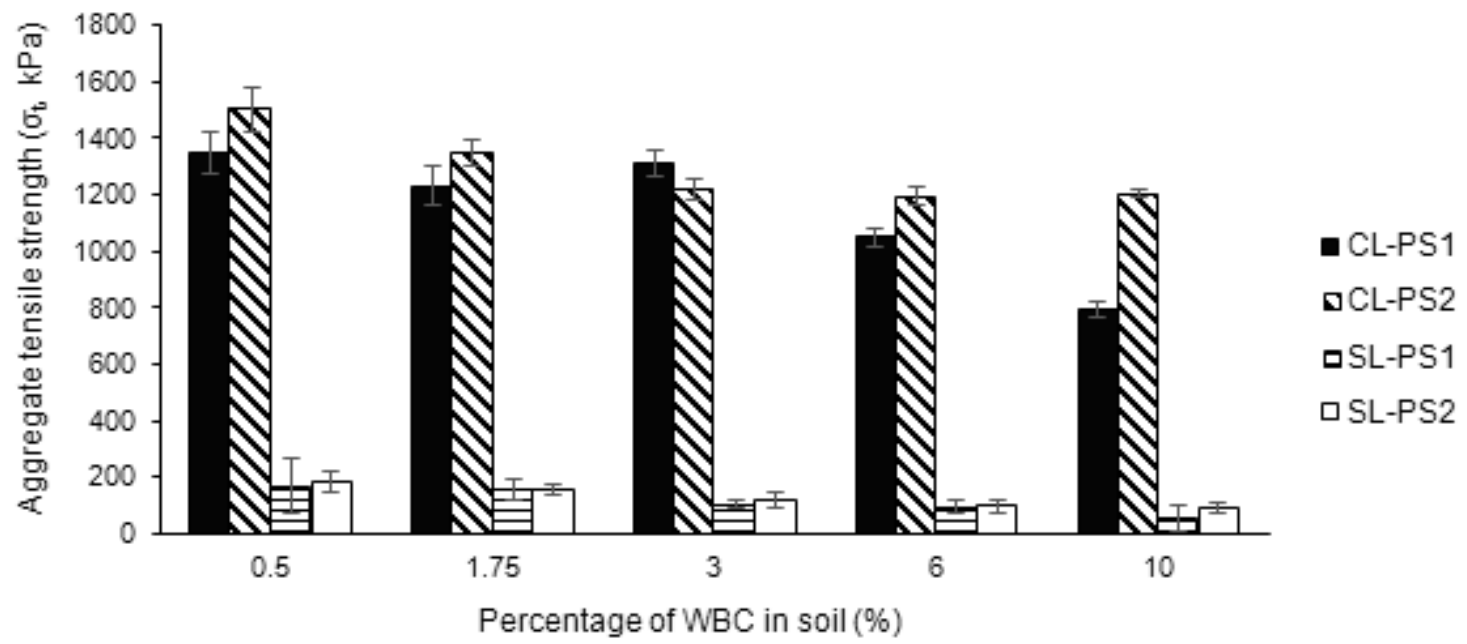

Fig. 6. Aggregate tensile strength $\left(\sigma_{t}\right)$ of $\mathrm{CL}$ and SL soils amended at different rates with small particle size $\left.\left(\mathrm{WBC}^{-\mathrm{PS}}\right)_{1}\right)$ and large particle size $\left(\mathrm{WBC}-\mathrm{PS}_{2}\right) \mathrm{WBC}$.

Table 4. The TS, FI and W of the CL and SL soils as amended with $10 \% \mathrm{WBC}$ of various particle sizes

\begin{tabular}{|c|c|c|c|c|}
\hline Treatment & Tensile strength & $F I$ & Classification & Workability \\
\hline $\mathrm{CL}$ & 1499.5 & 0.46 & & 691 \\
\hline CL-WBC-PS ${ }_{1}-10 \%$ & 427.5 & 0.24 & Friable & 102.53 \\
\hline CL-WBC-PS $2-10 \%$ & 1204 & 0.47 & & 658.32 \\
\hline SL & 177.5 & 0.06 & & 10.61 \\
\hline SL-WBC-PS ${ }_{1}-10 \%$ & 58.5 & 0.08 & Non Friable & 4.95 \\
\hline SL-WBC-PS $-10 \%$ & 182.5 & 0.14 & & 24.75 \\
\hline
\end{tabular}


Tab le 5. Chemical composition of WBC of two particle size ranges, and of the two experimental soils (clay loam and sandy loam)

\begin{tabular}{cccccccccc}
\hline \multirow{2}{*}{ Treatment } & $\begin{array}{c}\text { Particle size } \\
\text { range }\end{array}$ & $\mathrm{pH}$ & $\mathrm{OMC} \%$ & $\mathrm{P}$ & $\mathrm{K}$ & $\mathrm{Ca}$ & $\mathrm{Mg}$ & $\mathrm{Al}$ \\
\cline { 5 - 8 } WBC & $0.5-425 \mu \mathrm{m}$ & 8 & $\mathrm{NA}$ & 65.5 & 783 & 1353 & 95.6 & 96.4 \\
& $425-850 \mu \mathrm{m}$ & 7.9 & $\mathrm{NA}$ & 28.1 & 527 & 626.4 & 53.5 & 126 \\
\multirow{2}{*}{ Soil } & Clay loam & 5.8 & 4.1 & 66 & 165 & 1318 & 251.1 & 1143.4 \\
& Sandy loam & 6.3 & 5.4 & 148 & 31.1 & 1316 & 79.4 & 1369 \\
\hline
\end{tabular}

Table 6. Chemical composition of mixtures of WBC of two particle size ranges, applied at different rates to the clay loam or sandy loam soils

\begin{tabular}{|c|c|c|c|c|c|c|c|c|c|c|c|c|c|c|}
\hline \multirow{4}{*}{$\begin{array}{l}\text { Biochar } \\
\text { amendment } \\
\text { (\% dry } \\
\text { weight }\end{array}$} & \multicolumn{14}{|c|}{ Biochar particle diameter } \\
\hline & \multicolumn{7}{|c|}{$0.5-425 \mu \mathrm{m}-\mathrm{PS}_{1}$} & \multicolumn{7}{|c|}{$425-850 \mu \mathrm{m}-\mathrm{PS}_{2}$} \\
\hline & \multirow{2}{*}{$\mathrm{pH}$} & \multirow{2}{*}{$\begin{array}{c}\mathrm{OMC} \\
\%\end{array}$} & $\mathrm{P}$ & K & $\mathrm{Ca}$ & $\mathrm{Mg}$ & $\mathrm{Al}$ & \multirow{2}{*}{$\mathrm{pH}$} & \multirow{2}{*}{$\begin{array}{c}\text { OMC } \\
\%\end{array}$} & $\mathrm{P}$ & K & $\mathrm{Ca}$ & $\mathrm{Mg}$ & $\mathrm{Al}$ \\
\hline & & & & & $\mathrm{mg} \mathrm{kg}^{-1}$ & & & & & \multicolumn{5}{|c|}{$\mathrm{mg} \mathrm{kg}^{-1}$} \\
\hline & \multicolumn{14}{|c|}{ Clay loam } \\
\hline 3 & 5.7 & 4.6 & 47 & 114 & 1323 & 241.5 & 1094 & 5.8 & 4.9 & 48.8 & 125.0 & 1298 & 240.6 & 1105 \\
\hline 6 & 5.8 & 6 & 47.8 & 123.2 & 1331 & 237.4 & 1119 & 5.8 & 5.8 & 46.9 & 125.2 & 1304 & 236.8 & 1071 \\
\hline \multirow[t]{2}{*}{10} & 5.8 & 7.2 & 52.5 & 135.5 & 1323 & 234.6 & 1096 & 5.7 & 7.1 & 47.3 & 125.6 & 1288 & 228.5 & 1060 \\
\hline & \multicolumn{14}{|c|}{ Sandy loam } \\
\hline 3 & 6.6 & 5.8 & 150 & 39.5 & 1326 & 73 & 1332 & 6.4 & 5.7 & 157 & 29.4 & 1319 & 76.1 & 1372 \\
\hline 6 & 6.6 & 6.6 & 164.4 & 42.4 & 1340 & 71.2 & 1475.7 & 6.3 & 6.4 & 184.6 & 43.8 & 1360 & 50.4 & 1509.5 \\
\hline 10 & 6.7 & 8.4 & 154.2 & 67.6 & 1340 & 76.8 & 1391 & 6.6 & 7.3 & 175.4 & 46.2 & 1343 & 52.1 & 1425.6 \\
\hline
\end{tabular}

soil OM content increased from 21.5 to $36.26 \mathrm{~g} \mathrm{~kg}^{-1}$, and the available $\mathrm{P}$ and $\mathrm{K}$ showed no significant changes when $2 \% \mathrm{WBC}$ was added to the soil and the mixture was incubated for 135 days (Li et al., 2016). However, Lehmann et al. (2003), Novak et al. (2009), Steiner et al. (2008), and Zong et al. (2016) reported that WBC addition to soil significantly increased the soil $\mathrm{pH}$, and total $\mathrm{C}$ and available $\mathrm{K}$ and $\mathrm{P}$ concentrations. These differences could be attributed to the fact that the soil in this study was incubated for only a week.

\section{CONCLUSIONS}

1. The workability increased when relatively coarse wood-derived biochar was applied to clay loam soil at dosages of 6 or $10 \%$. It is recommended that coarser wood- derived biochar is applied to clay loam soil to prevent destruction of the soil structure because finer wood-derived biochar particles render clay loam soil less friable.

2. Wood-derived biochar addition could improve fertility depending on the particle size of the wood-derived biochar and the soil texture. The clay loam fertility was not affected by particle size.

3. Wood-derived biochar amendment increased the plasticity index of the clay loam soil, thereby increasing the range of moisture within which the clay loam soil is most susceptible to compaction. Wood-derived biochar amendment increased the affinity of the clay loam soil for water requiring more water to behave in a plastic or liquid manner. Moreover, increasing the water content at optimum moisture content and plastic limit may imply that soil could exhibit same deformation and a similar workable range. 
Conflict of interest: The Authors do not declare conflict of interest.

\section{REFERENCES}

ASTM Standard D4318, 2010. Standard Test Methods for Liquid Limit, Plastic Limit, and Plasticity Index of Soils. ASTM International, West Conshohocken, PA, USA.

ASTM Standard D698, 2007. Standard Test Methods for Laboratory Compaction Characteristics of Soil Using Standard Effort (12 $400 \mathrm{ft}-\mathrm{lbf} / \mathrm{ft} 3(600 \mathrm{kN}-\mathrm{m} / \mathrm{m} 3))$. ASTM International, West Conshohocken, PA.

ASTM Standard D3080/D3080M-11, 2005. Standard Test Method for Direct Shear Test of Soils Under Consolidated Drained Conditions. ASTM International, West Conshohocken, PA.

ASTM Standard D7928, 2017. Standard Test Method for ParticleSize Distribution (Gradation) of Fine-Grained Soils Using the Sedimentation (Hydrometer) Analysis. ASTM Int., West Conshohocken, PA, USA.

ASTM International, 2013. ASTM D1762-84(2013), standard test method for chemical analysis of wood charcoal. West Conshohocken, PA: ASTM International. https://doi. org/10.1520/D1762

Arthur E., Schjonning P., Moldrup P., Razzaghi F., Tuller M., and De Jonge L.W., 2014. Soil structure and microbial activity dynamics in 20-month field-incubated organic-amended soils. European J. Soil Sci., 65(2), 218-230.

Barzegar A., Asoodar M., and Ansari M., 2000. Effectiveness of sugarcane residue incorporation at different water contents and the Proctor compaction loads in reducing soil compactibility. Soil Till. Res., 57(3), 167-172.

Blanco-Moure N., Angurel L.A., Moret-Fernández D., and López M.V., 2012. Tensile strength and organic carbon of soil aggregates under long-term no tillage in semiarid Aragon (NE Spain). Geoderma, 189, 423-430.

Brewer C.E., Chuang V.J., Masiello C.A., Gonnermann H., Gao X., Dugan B., Driver L.E., Panzacchi P., Zygourakis K., and Davies C.A., 2014. New approaches to measuring biochar density and porosity. Biomass Bioenergy, 66, 176-185.

Carter M.R., 1993. Soil sampling and methods of analysis. CRC Press, Lewis Publisher, Boca Raton - London - New York - Washington.

Cimò G., Kucerik J., Berns A.E., Schaumann G.E., Alonzo G., and Conte P., 2014. Effect of heating time and temperature on the chemical characteristics of biochar from poultry manure. J. Agric. Food Chem., 62(8), 1912-1918.

Craig R.F., 1974. Soil Mechanics. Van Nostrand Reinhold, New York, USA.

Dexter A.R. and Kroesbergen B., 1985. Methodology for determination of tensile strength of soil aggregates. J. Agric. Eng. Res., 31, 139-147.

Dexter A.R. and Bird N.R.A., 2000. Methods for predicting the optimum and the range of soil water contents for tillage based on the water retention curve. Soil Till. Res., 57(4): 203-212. https://doi.org/10.1016/S0167-1987(00)00154-9
EImholt S., Schjønning P., Munkholm L.J., and Debosz K., 2008. Soil management effects on aggregate stability and biological binding. Geoderma, 144(3), 455-467.

Getahun G.T., Munkholm L.J., and Schjønning P., 2016. The influence of clay-to-carbon ratio on soil physical properties in a humid sandy loam soil with contrasting tillage and residue management. Geoderma, 264, 94-102.

Guo Y., Tang H., Li G., and Xie D., 2014. Effects of cow dung biochar amendment on adsorption and leaching of nutrient from an acid yellow soil irrigated with biogas slurry. Water, Air, Soil Pollution, 225(1), 1-13.

Hendershot W., Lalande H., and Duquette M., 1993. Ion exchange and exchangeable cations. Soil Sampling Methods of Analysis, 19, 167-176.

Imhoff S., Da Silva A.P., and Dexter A., 2002. Factors contributing to the tensile strength and friability of Oxisols. Soil Sci. Soc. America J., 66(5), 1656-1661.

Larson W., Gupta S., and Useche R., 1980. Compression of agricultural soils from eight soil orders. Soil Soil Sci. Soc. America J., 44(3), 450-457.

Lehmann J., Pereira da Silva J., Steiner C., Nehls T., Zech W., and Glaser B., 2003. Nutrient availability and leaching in an archaeological Anthrosol and a Ferralsol of the Central Amazon basin: fertilizer, manure and charcoal amendments. Plant Soil, 249(2), 343-357.

Li M., Liu M., Li Z.-P., Jiang C.-Y., and Wu M., 2016. Soil N transformation and microbial community structure as affected by adding biochar to a paddy soil of subtropical China. J. Integrative Agric., 15(1): 209-219. https://doi. org/10.1016/S2095-3119(15)61136-4

Lu S.-G., Sun F.-F., and Zong Y.-T., 2014. Effect of rice husk biochar and coal fly ash on some physical properties of expansive clayey soil (Vertisol). Catena, 114, 37-44.

Mapfumo E. and Chanasyk D.S., 1998. Guidelines for safe trafficking and cultivation, and resistance-density-moisture relations of three disturbed soils from Alberta. Soil and Tillage Research, 46(3-4), 193-202. doi: 10.1016/ S0167-1987(98)00100-7

Mehlich A., 1984. Mehlich 3 soil test extractant: A modification of Mehlich 2 extractant. Communications in Soil Science Plant Analysis, 15(12), 1409-1416.

Mitchell P.J., Simpson A.J., Soong R., and Simpson M.J., 2015. Shifts in microbial community and water-extractable organic matter composition with biochar amendment in a temperate forest soil. Soil Biol. Bioch., 81, 244-254.

Novak J.M., Busscher W.J., Laird D.L., Ahmedna M., Watts D.W., and Niandou M.A., 2009. Impact of biochar amendment on fertility of a southeastern coastal plain soil. Soil Sci., 174(2), 105-112.

Qu J., Li B., Wei T., Li C., and Liu B., 2014. Effects of rice-husk ash on soil consistency and compactibility. Catena, 122, 54-60.

Rees F., Simonnot M.-O., and Morel J.-L., 2014. Short-term effects of biochar on soil heavy metal mobility are controlled by intra-particle diffusion and soil $\mathrm{pH}$ increase. European J. Soil Sci., 65(1), 149-161.

Reis D.A., Lima C.L.R.d., Pauletto E.A., Dupont P.B., and Pillon C.N., 2014. Tensile strength and friability of an Alfisol under agricultural management systems. Scientia Agricola, 71(2), 163-168. 
Slepetiene A., Slepetys J., and Liaudanskiene I., 2008. Standard and modified methods for soil organic carbon determination in agricultural soils. Agron. Res., 6(2), 543-554.

Steiner C., Glaser B., Geraldes Teixeira W., Lehmann J., Blum W.E., and Zech W., 2008. Nitrogen retention and plant uptake on a highly weathered central Amazonian Ferralsol amended with compost and charcoal. J. Plant Nutrition Soil Sci., 171(6), 893-899.

Utomo W. and Dexter A., 1981. Soil friability. J. Soil Sci., 32(2), 203-213.
Watts C. and Dexter A., 1998. Soil friability: theory, measurement and the effects of management and organic carbon content. European J. Soil Sci., 49(1), 73-84.

Yuan H., Lu T., Wang Y., Huang H., and Chen Y., 2014. Influence of pyrolysis temperature and holding time on properties of biochar derived from medicinal herb (radix isatidis) residue and its effect on soil $\mathrm{CO}_{2}$ emission. J. Analytical Appl. Pyrolysis, 110, 277-284.

Zong Y., Xiao Q., and Lu S., 2016. Acidity, water retention, and mechanical physical quality of a strongly acidic Ultisol amended with biochars derived from different feedstocks. J. Soils Sediments, 16(1), 177-190. 